\title{
Interactions between nitrogen deposition, land cover conversion, and climate change determine the contemporary carbon balance of Europe
}

\author{
G. Churkina ${ }^{1,2}$, S. Zaehle ${ }^{2}$, J. Hughes ${ }^{3}$, N. Viovy ${ }^{4}$, Y. Chen ${ }^{2}$, M. Jung ${ }^{2}$, B. W. Heumann ${ }^{5,6}$, N. Ramankutty ${ }^{5}$, \\ M. Heimann ${ }^{2}$, and C. Jones ${ }^{3}$ \\ ${ }^{1}$ Leibniz-Centre for Agricultural Landscape Research, Eberswalderstr. 84, 15374 Müncheberg, Germany \\ ${ }^{2}$ Max-Planck Institute for Biogeochemistry, Hans-Knöll-Str. 10, 07745 Jena, Germany \\ ${ }^{3}$ Met Office Hadley Centre, FitzRoy Road, Exeter, Devon, EX1 3PB, UK \\ ${ }^{4}$ Laboratoire des Sciences du Climat et de l'Environnement, CEA-CNRS-UVSQ, 91191 Gif-sur-Yvette, France \\ ${ }^{5}$ Department of Geography \& Earth System Science Program, McGill University, 805 Sherbrooke St. W., Montreal, \\ QC H3A 2K6, Canada \\ ${ }^{6}$ Department of Geography, University of North Carolina at Chapel Hill, Saunders Hall, Campus Box 3220, Chapel Hill, NC \\ 27599-3220, USA
}

Received: 22 February 2010 - Published in Biogeosciences Discuss.: 29 March 2010

Revised: 13 August 2010 - Accepted: 31 August 2010 - Published: 20 September 2010

\begin{abstract}
European ecosystems are thought to take up large amounts of carbon, but neither the rate nor the contributions of the underlying processes are well known. In the second half of the 20th century, carbon dioxide concentrations have risen by more that $100 \mathrm{ppm}$, atmospheric nitrogen deposition has more than doubled, and European mean temperatures were increasing by $0.02{ }^{\circ} \mathrm{C} \mathrm{yr}^{-1}$. The extents of forest and grasslands have increased with the respective rates of $5800 \mathrm{~km}^{2} \mathrm{yr}^{-1}$ and $1100 \mathrm{~km}^{2} \mathrm{yr}^{-1}$ as agricultural land has been abandoned at a rate of $7000 \mathrm{~km}^{2} \mathrm{yr}^{-1}$. In this study, we analyze the responses of European land ecosystems to the aforementioned environmental changes using results from four process-based ecosystem models: BIOME-BGC, JULES, ORCHIDEE, and O-CN. The models suggest that European ecosystems sequester carbon at a rate of $56 \mathrm{TgC} \mathrm{yr}^{-1}$ (mean of four models for 19512000) with strong interannual variability $\left( \pm 88 \mathrm{TgC} \mathrm{yr}^{-1}\right.$, average across models) and substantial inter-model uncertainty $\left( \pm 39 \mathrm{TgC} \mathrm{yr}^{-1}\right)$. Decadal budgets suggest that there has been a continuous increase in the mean net carbon storage of ecosystems from $85 \mathrm{TgC} \mathrm{yr}^{-1}$ in 1980 s to $108 \mathrm{TgC} \mathrm{yr}^{-1}$ in 1990s, and to $114 \mathrm{TgC} \mathrm{yr}^{-1}$ in 2000-2007. The physiologi-
\end{abstract}

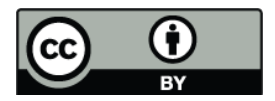

Correspondence to: G. Churkina (galina@ churkina.org) cal effect of rising $\mathrm{CO}_{2}$ in combination with nitrogen deposition and forest re-growth have been identified as the important explanatory factors for this net carbon storage. Changes in the growth of woody vegetation are suggested as an important contributor to the European carbon sink. Simulated ecosystem responses were more consistent for the two models accounting for terrestrial carbon-nitrogen dynamics than for the two models which only accounted for carbon cycling and the effects of land cover change. Studies of the interactions of carbon-nitrogen dynamics with land use changes are needed to further improve the quantitative understanding of the driving forces of the European land carbon balance.

\section{Introduction}

The contemporary land carbon balance is affected by ecosystem responses to climate variations, land management, changes in atmospheric composition such as the deposition of reactive nitrogen or the increase in $\mathrm{CO}_{2}$ concentrations, as well as the interactive effects of these factors in the past (Schimel et al., 2001). Compilations of various data streams ranging from eddy-covariance measurements to forest inventories and site-level modeling suggest that European ecosystems are a sink of carbon in the order of $135-205 \mathrm{TgC}^{-1}$ (Janssens et al., 2003) or $185-285 \mathrm{TgC} \mathrm{yr}^{-1}$ (Schulze et al.,

Published by Copernicus Publications on behalf of the European Geosciences Union. 
2009). Schulze at al. (2009) and Janssens et al. (2003) discuss possible contributions of different vegetation types to this sink, however, their methodology prevents them from attributing the net carbon balance to various processes ongoing in the vegetation. The possible driving forces of the land carbon uptake in Europe have been discussed in the literature. These include past trends in climate, atmospheric $\mathrm{CO}_{2}$ and land cover changes (Zaehle et al., 2007), a growing discrepancy between the increase in timber harvests in comparison to increases to forest biomass (Ciais et al., 2008b), deposition of reactive nitrogen (Magnani et al., 2007) and the combined effects of changing environmental conditions and forest regrowth (Churkina et al., 2007; Vetter et al., 2005).

The land carbon balance, Net Ecosystem Exchange (NEE), is defined as the difference between the carbon assimilated by plants through photosynthesis and the carbon emitted through auto- and heterotrophic respiration, as measured in site-level studies. At the landscape level, disturbance by fire or biomass harvest, as well as export of organic carbon into rivers and seas further modify the NEE and return $\mathrm{CO}_{2}$ to the atmosphere or alter rates and place of organic carbon decomposition. The resulting Net Biome Productivity (NBP) is the long-term carbon gain or loss of terrestrial biomass and soil pools, describes the net storage of carbon in terrestrial ecosystems, and thereby whether or not a particular region play a role in reducing or increasing atmospheric $\mathrm{CO}_{2}$ levels. Process-based models allow to integrate the individual driving forces of the terrestrial carbon balance in different land cover types into a comprehensive framework.

Here we provide a comprehensive assessment of the contemporary terrestrial carbon balance of Europe and its most important driving forces. We analyze the relative roles of rising atmospheric $\mathrm{CO}_{2}$, increasing deposition of nitrogen, changes in climate, and land cover conversion in increasing land carbon uptake in Europe between 1950 and 2007, although no single model or simulation is yet able to consider all of these forcings together. We estimate the evolution of European carbon balance over the 20th century with three ecosystem models BIOME-BGC, JULES, and ORCHIDEE driven with a consistent set of model drivers to allow for a meaningful comparison across the models. To corroborate the findings of the only carbon-nitrogen cycle model used in the study (BIOME-BGC), we present also results from a fourth ecosystem model $(\mathrm{O}-\mathrm{CN})$, which extends the ORCHIDEE model inter alia by a representation of nitrogen dynamics. We then assess the degree of agreement between the estimates from process-based models with independent, data-driven estimates obtained from recent bottomup compilation of field studies and from top-down inverse calculations by atmospheric transport models relying on atmospheric measurements of $\mathrm{CO}_{2}$ concentrations.

\section{Materials and methods}

\subsection{Models' description}

In this study, we use four process-based terrestrial ecosystem models: BIOME-BGC, JULES, ORCHIDEE, as well as its nitrogen cycle version $\mathrm{O}-\mathrm{CN}$ to simulate carbon fluxes. All models simulate gross primary productivity and respiration independently. The models differ by the number of simulated ecosystem types as well as by implementation of land use conversion algorithm. BIOME-BGC and O-CN simulate nitrogen cycle and carbon-nitrogen interactions explicitly, but do not model effects of land cover conversion. JULES and ORCHIDEE simulate effects of land cover conversion, but not nitrogen cycle. All models estimate NEE as a difference between gross photosynthetic uptake and ecosystem respiration. ORCHIDEE and JULES estimate also NBP as a difference between NEE and harvest. Descriptions of photosynthesis, respiration and the water cycle in the models are summarized in (Vetter et al., 2008). Below we give only a general overview of the models' concepts.

BIOME-BGC: BIOME-BGC is a process model describing the carbon, nitrogen, and water cycles within terrestrial ecosystems (Running and Gower, 1991; Thornton, 1998). It has been corroborated for a number of hydrological and carbon cycle components (Churkina et al., 2003; Thornton et al., 2002; Churkina and Running, 2000). In this study BIOME-BGC was parameterized for seven vegetation types including evergreen needleleaf, evergreen broadleaf, deciduous needleleaf, deciduous broadleaf, shrubs, as well as grass with $\mathrm{C} 3$ and $\mathrm{C} 4$ type photosynthesis. Ecophysiological parameters were estimated using eddy covariance measurements for evergreen needleleaf and broadleaf deciduous forests (Trusilova et al., 2009) and for C3 grasslands (Tomelleri, 2007). General parameters were used for the other vegetation types (White et al., 2000). Croplands were simulated as $\mathrm{C} 3$ grasslands which productivity is unlimited by nitrogen availability. Forest management was not included in these simulations.

Joint UK Land Environment Simulator (JULES): JULES is a land-surface model based on the MOSES2 land surface scheme (Essery et al., 2003) used in the Hadley Centre climate model HadGEM (Johns et al., 2006), also incorporating the TRIFFID DGVM (Cox, 2001; Cox et al., 2000). The model simulates carbon, water and energy fluxes of five plant functional types: broadleaf and needleleaf forests, $\mathrm{C} 3$ and $\mathrm{C} 4$ grasses, and shrubs. In this study conversion of vegetation types within each grid cell was modeled internally based on Lotka-Volterra competition equations driven by predicted rates of photosynthesis. A basic dominance hierarchy is assumed: trees replace shrubs and grasses, shrubs replace grasses, croplands displace all natural vegetation.

When shrubs and trees are displaced by land use expansion, the removed carbon is either passed to the wood product pool or added to the soil carbon pool following the rules from 
Table 1. Fate of biomass after land cover conversion or harvest in simulations of model including effects of land cover conversion on carbon cycle (after Zaehle et al., 2007).

\begin{tabular}{lccl}
\hline & \multicolumn{2}{c}{ Proportion of biomass left on site } & \\
\cline { 2 - 3 } Land use type & Aboveground & Belowground & Harvested biomass [\%] \\
\hline Forest & leaves 100 wood 40 & 100 & 60 (wood only) \\
Grassland & Leaves 100 & 100 & 0 \\
Cropland & 10 & 100 & 90 (leaves and grain) \\
Pasture & 50 & 100 & 50 leaves \\
\hline
\end{tabular}

Table 1. Forest was considered harvested only if its fractional coverage within grid cell decreased due to the expansion of land use. To represent crops, the carbon fluxes of grasses were modified in regions dominated by croplands. A fraction of NPP from grass-crops was diverted from the natural vegetation carbon pools into an external crop harvest pool, which was considered separate to the wood products pool from forest clearance. The default methodology in JULES is to assume no lateral transport of carbon between grid cells. Carbon from crop harvest is respired back to the atmosphere in one year. Carbon from wood product pool is respired back to the atmosphere on timescales of one, ten, and 100 years.

ORCHIDEE: The ORCHIDEE biosphere model describes the carbon, energy and water fluxes (Krinner et al., 2005; Viovy, 1996) at a half hourly time-step. Input daily climate data are converted to half hourly data using a weather generator. ORCHIDEE differentiates between 12 plant functional types, including temperate broadleaf evergreen, temperate and boreal needleleaf evergreen as well as broadleaf deciduous and boreal needleleaf deciduous trees. Herbaceous plants are represented either as natural $\mathrm{C} 3$ and $\mathrm{C} 4$ grasslands, or as managed C3 and C4 croplands. An improved cropland phenology was applied in the model simulations. Improved crop phenology mimics the phenology of winter wheat for C3crops with an early leaf onset day and a short growing season, and of maize for $\mathrm{C} 4$ crops with a late onset day of leaves, based on meteorological parameters. ORCHIDEE does not take into account crop or forest management practices.

After land cover conversion or harvest, carbon was distributed between different pools following the rules from Table 1. Forest was harvested only if its fraction within grid cell decreased. Harvested biomass of forests is decomposed within one, ten, or 100 years. Different decomposition times of harvested biomass reflect life time of forest products. A fraction of crop biomass was removed to simulate harvest. Thereafter it was decomposed within one year, which was the year of harvest. Biomass removed with harvest of forest or crops stayed in the same grid cell where it was harvested.

O-CN: ORCHIDEE has been advanced by adding a comprehensive nitrogen cycle representation as well as revising the representation of vegetation structure and growth (Zaehle and Friend, 2010; Zaehle et al., 2010). Simulations of this new model only became available after the main study had been conducted. The model simulations were performed with a slightly different set of drivers and at a much coarser spatial resolution (see below). To corroborate the findings of the only carbon-nitrogen cycle model used in the study (BIOME-BGC) we present also results from O-CN model runs.

\subsection{Models' environmental drivers}

As input drivers ecosystem models require climate variables, elevation above the sea level, soil texture, soil depth, fractional land use maps, atmospheric $\mathrm{CO}_{2}$ concentrations, and nitrogen deposition (models including nitrogen deposition only). All models except $\mathrm{O}-\mathrm{CN}$ used the same maps of elevation above the sea level, soil texture, soil-depth, atmospheric $\mathrm{CO}_{2}$ concentrations, and climate drivers at $0.25^{\circ} \times 0.25^{\circ}$ spatial resolution. The elevation above sea level, soil texture, and soil-depth data are described elsewhere (Vetter et al., 2008). The atmospheric $\mathrm{CO}_{2}$ concentrations were based on the ice core data from (Etheridge et al., 1996) and atmospheric measurements from Mauna Loa (Keeling and Whorf, 2005). The $\mathrm{CO}_{2}$ concentrations data covered the time from 1700 until the end of 2007.

\subsubsection{Climate}

Climate variables were from the modified Climate Research Unit (MCRU) dataset (Chen et al., 2009), which is based on combination of monthly data from Climate Research Unit (CRU), Norwich, UK database (CRU, 2007) and daily meteorological variables from ECHAM5 and REMO climate model simulations. ECHAM5 is the 5th generation of the ECHAM general circulation model driven by changes in greenhouse gases and aerosols (ECHAM5, 2007) developed at the Max-Planck Institute for Meteorology, Hamburg, Germany. REMO (REgionalMOdel, Jacob and Podzun, 1997) is a regional climate model forced at the boundaries with variables from global 6-hourly NCEP (National Center for Environmental Prediction) reanalysis data set (Kalnay et al., 1996) from 1948 until 2007. A more detailed description of the multi-decadal REMO simulation is given in Feser et 
al. (2001). MCRU data set provides daily climate variables from 1861 until 2007. For the period 1700-1860 models used MCRU climate for 1901-1930, repetitively.

\subsubsection{Atmospheric nitrogen deposition}

Annual estimates of atmospheric nitrogen deposition for 1860-2007 were used to drive simulations of models with nitrogen cycle. These estimates for Europe were extracted from a global dataset at $1^{\circ} \times 1^{\circ}$ spatial resolution for 1860 2030. The global dataset was created using estimates from the three dimensional atmospheric chemical transport model TM3 (Rodhe et al., 2002) for 1860-1980 and the mean of an ensemble of model results (Dentener et al., 2006) for 2000 and 2030. For each grid cell nitrogen deposition was linearly interpolated for 1980-2000 and 2000-2030. The estimates included wet and dry depositions of both $\mathrm{NO}_{\mathrm{y}}$ and $\mathrm{NH}_{\mathrm{x}}$. The depositions of reactive nitrogen between 2000 and 2007 were estimated with a "high emission" scenario which corresponds to the IPCC SRES A2 scenario. The original decadal model outputs for 1860-1980 as well as for 2000 and 2030 were transformed into time series of annual atmospheric nitrogen depositions using linear interpolation between available data for each grid cell.

\subsubsection{Land cover}

Fractional land use maps with annual time step for 1700 2000 at $0.25^{\circ}$ for Europe were available for this study. These maps are a combination of historical croplands/pastures maps with a vegetation classification map adjusted for carbon cycle modeling (SYNMAP, Jung et al., 2006). Historical cropland/pasture maps were derived using hindcasting techniques similar to those of Ramankutty and Foley (1999), by combining historical agricultural census data at the national and subnational levels with remote-sensing cropland/pasture maps for year 2000 from Ramankutty et al. (2008). In this version, a much richer historical census database was used for most of Europe. National-level data from 1961-2000 were obtained for all 36 nations from the Food and Agriculture Organization (FAO, http://faostat.fao.org). Nationallevel data from FAO provides statistics at a country level, where the smallest spatial unit is one country. Further, we compiled subnational statistics for 248 administrative units from various sources. Data for 19 countries, with the earliest data available for 1974 in the best case, were obtained from EUROSTAT database (http://epp.eurostat.ec.europa.eu) at the second administrative level of Nomenclature of Territorial Units for Statistics (NUTS2). Data from various other individual national reports (Economic Research Service, 1975; Committee for the World Atlas of Agriculture, 1969; EUROSTAT, 1993; Norwegian Census of Agriculture, 1991; Bouzaher et al., 1994; Organization for Economic Cooperation and Development, 1996) were used to fill some of the gaps in this database. Extrapolation from the ear- liest available data was used to fill other gaps, which occurred mainly during the 1950-1961 period. Annual maps of land cover were produced by superimposing the fractions of croplands/pastures with a map of potential vegetation derived from SYNMAP (potential SYNMAP, see the online materials in Churkina et al., 2009).

Because of grid cell-wise inconsistencies between the crop and pasture area of historical maps and the crop area of SYNMAP, adjustments of the fractions of the natural vegetation types from SYNMAP are necessary. By using a map of reconstructed natural vegetation compatible with SYNMAP or potential SYNMAP, it is possible to account for preferential conversion of natural vegetation types into crops or pastures within each grid cell. The fraction of a natural vegetation type $(F)$ is calculated as:

$F=F_{\text {pot }}-x \cdot\left(F_{\text {pot }}-F_{\text {act }}\right)$

The subscripts "pot" and "act" refer to the fractions of the vegetation type for potential and actual SYNMAPs respectively. The factor $x$ scales the difference between the fractions of potential and actual vegetation types. It is calculated as the ratio between the crop $\left(\mathrm{CROP}_{\text {rec }}\right)$ and pasture $\left(\right.$ PASTURE $_{\text {rec }}$ ) fractions of historical maps and the crop frac-

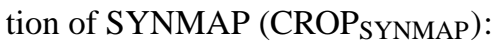

$x=\left(\mathrm{CROP}_{\text {rec }}+\right.$ PASTURE $\left._{\text {rec }}\right) / \mathrm{CROP}_{\text {SYNMAP }}$.

\subsubsection{Drivers of O-CN}

$\mathrm{O}-\mathrm{CN}$ was driven at a $2^{\circ} \times 2^{\circ}$ spatial resolution with the same atmospheric $\mathrm{CO}_{2}$ and nitrogen deposition data, however, using observations of the monthly CRU meteorology directly as input for 1901-2002 (Mitchell et al., 2004). Land cover was assumed to be constant at 1995 levels (Loveland et al., 2000).

\subsection{Models' simulations}

All models were initialized with the assumptions that the ecosystem carbon stocks and fluxes were in equilibrium in 1700. To achieve this equilibrium, spin-up simulations were performed with repeated MCRU climate for 1901-1930 and constant $\mathrm{CO}_{2}$ concentrations for 1700 . In JULES and ORCHIDEE land use maps for 1700 were used in spin-up run. In BIOME-BGC and O-CN land use maps for 2000 and 1995 respectively as well as pre-industrial nitrogen deposition were employed. The major reason behind different land use maps used by models in equilibrium run is consistency of that map with the map in the first year of transient simulations. If these two maps are not consistent, a model may simulate abnormal carbon fluxes in the first few decades of transient simulations, which is a result of abrupt changes in land use types. Because JULES and ORCHIDEE simulate changes in land use, they used the year 1700 map for equilibrium simulations and annual land use maps from 1700 until 2000 for transient simulations as inputs. As BIOME-BGC 
Table 2. Protocol of transient models' simulations.

\begin{tabular}{lcccc}
\hline $\begin{array}{l}\text { Model } \\
\text { Simulation }\end{array}$ & $\begin{array}{l}\text { Climate } \\
\text { Change }\end{array}$ & $\begin{array}{l}\text { Change in Atmospheric } \\
\mathrm{CO}_{2} \text { Concentrations }\end{array}$ & $\begin{array}{l}\text { Change in Atmospheric } \\
\text { Depositions of } \mathrm{NO}_{\mathrm{y}} \\
\text { and } \mathrm{NH}_{\mathrm{x}}{ }^{\mathrm{a}}\end{array}$ & $\begin{array}{l}\text { Land Cover } \\
\text { Conversion }\end{array}$ \\
\hline $\begin{array}{l}\text { Reference } \\
\mathrm{Clim}\end{array}$ & No & No & No & No \\
$\mathrm{Clim}+\mathrm{CO}_{2}$ & Yes & No & No & No \\
$\mathrm{Clim}+\mathrm{CO}_{2}+\mathrm{LUC}$ & Yes & Yes & No & No \\
$\mathrm{Clim}+\mathrm{CO}_{2}+\mathrm{N}$ & Yes & Yes & Yo & Yes \\
\hline
\end{tabular}

a Only for models including nitrogen cycle.

b Only for models including effects of land cover conversion.

and $\mathrm{O}-\mathrm{CN}$ do not incorporate land use changes in their simulations, they used recent land use maps for both equilibrium and transient simulations.

Three transient simulations were performed with different combinations of environmental drivers for 1700-2007 (Table 2). The first transient simulation, "Reference", was performed by four models without changes in climate, atmospheric $\mathrm{CO}_{2}$ concentrations, nitrogen deposition, and land cover. In the "Clim" simulation only changes in climate were implemented in all four models. In " $\mathrm{Clim}+\mathrm{CO}_{2}$ " simulation four models were driven by changes in climate and rising atmospheric $\mathrm{CO}_{2}$. In "Clim $+\mathrm{CO}_{2}+\mathrm{LUC}$ " simulation JULES and ORCHIDEE models were driven by changes in climate, increasing $\mathrm{CO}_{2}$, and land cover conversion. BIOME-BGC and $\mathrm{O}-\mathrm{CN}$ models were driven by changes in climate, rising $\mathrm{CO}_{2}$, and nitrogen deposition in " $\mathrm{Clim}+\mathrm{CO}_{2}+\mathrm{N}$ " simulation. Because MCRU data set covered only time period from 1861 until 2007, repeated climate for 1901-1930 was used for model simulations from 1700 until 1860. After 2000 fractions of cropland/pasture were assumed to be constant at 2000 values. Transient simulations of ORCHIDEE and JULES without land use change were performed with land cover for 1700 .

The models with land use change used different algorithms for conversion of land use types. ORCHIDEE prescribed annual conversion of vegetation types from the supplied dataset. In JULES, annual conversion of vegetation types within each grid cell was modeled internally as described above and was constrained by the prescribed land use distributions.

\subsection{Evaluation of changes in environmental drivers and carbon balance estimates}

Rates of change for all environmental drivers were calculated for Europe over the first and second half of the 20th century. We divided the 20th century into two periods (before and after 1950) to reflect different trends in the environmental drivers. Fast industrial growth in Europe and also in some other parts of the world was observed after the Second World
War which ended in 1945. Countries were rebuilding their industries and population was growing. Emissions of $\mathrm{CO}_{2}$ and $\mathrm{NO}_{\mathrm{x}}$ from energy production were rising fast. To meet the dietary needs of growing population, production of synthetic nitrogen fertilizers started in 1950's after the discovery of Haber-Bosch process in 1930's. Production and application of fertilizers increased amount of available inorganic nitrogen.

We evaluated responses of land ecosystems to environmental drivers for the second half of 20th century, because we aimed at understanding the roles of different drivers in the European carbon sink. Furthermore, more confidence can be placed into recent trends of land-cover changes because of the much increased level of documentation in land-use statistics.

The effects of individual drivers on the terrestrial carbon balance were attributed by comparing the different factorial experiments. For example, the effect of land-cover conversion was inferred by comparing simulations with climate and $\mathrm{CO}_{2}$ changes to that accounting for these changes in addition to land-cover changes.

To test statistical significance of model responses to individual environmental drivers, we have performed a Welch t-test of the model outputs, because this test does not require that the variances of the samples are equal. Welch t-test was applied to the net ecosystem exchange and carbon stock changes simulated with factorial experiments for 1951-2000. For each factorial experiment, we tested the hypotheses that the output from each model was equal to zero and that the average simulated net ecosystem exchange or stock changes were similar between the individual models. Statistical significance was tested with a threshold value of 0.05 .

\section{Results}

\subsection{Rates of change in major environmental drivers}

In the 20th century two periods with different rates of change in major environmental drivers of Europe can 


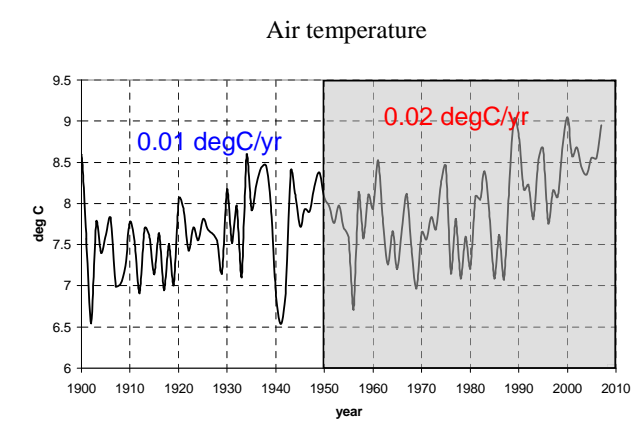

Atmospheric CO2 concentration

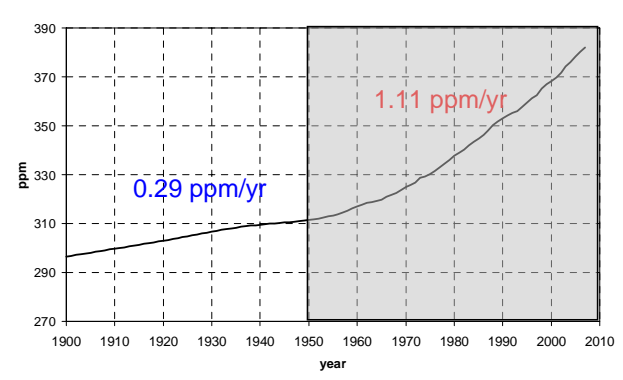

Atmospheric nitrogen deposition

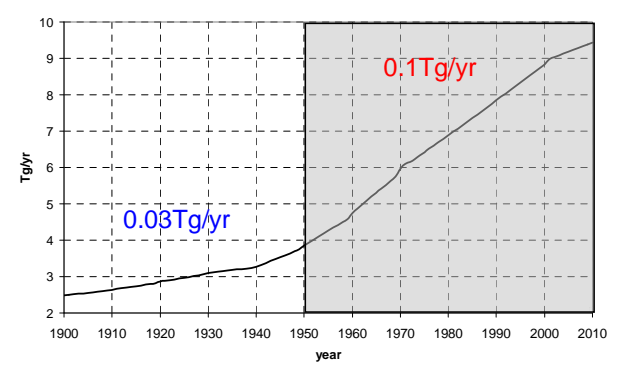

Land cover conversion

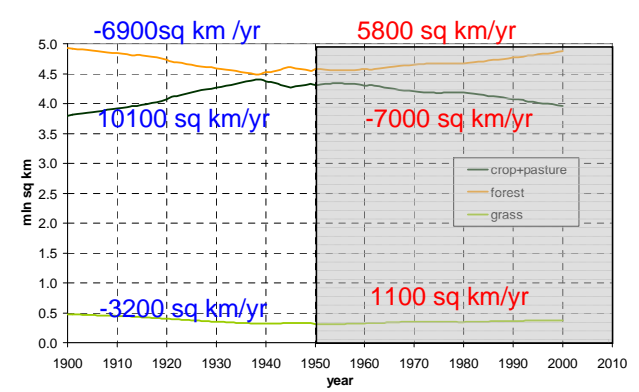

Fig. 1. Changes in major environmental drivers of carbon balance of Europe over 20th century. Annual values of average air temperature, atmospheric nitrogen deposition, and land cover conversion are calculated for the whole study domain. Atmospheric $\mathrm{CO}_{2}$ concentrations are calculated as global averages.

be distinguished: a period of slow changes from 1900 to about 1950 and a period of faster changes thereafter (Fig. 1). Between 1900 and 1950, atmospheric $\mathrm{CO}_{2}$ concentrations, nitrogen deposition, and temperatures increased only moderately. Their rates of change were $0.01^{\circ} \mathrm{C} \mathrm{yr}^{-1}$, $0.03 \mathrm{Tg} \mathrm{N} \mathrm{yr}^{-1}$, and $0.29 \mathrm{ppm} \mathrm{yr}^{-1}$ respectively. Forest (4.9 million $\mathrm{km}^{2}$ in 1900$)$ and grassland $\left(0.75\right.$ million $\mathrm{km}^{2}$ in 1900) extents declined with the rates of $6900 \mathrm{~km}^{2} \mathrm{yr}^{-1}$ $\left(0.14 \% \mathrm{yr}^{-1}\right)$ and $3200 \mathrm{~km}^{2} \mathrm{yr}^{-1}\left(0.67 \% \mathrm{yr}^{-1}\right)$, respectively. The area of land in agricultural use such as cropland and pasture (3.8 million $\mathrm{km}^{2}$ in 1900) increased with the rate of $10100 \mathrm{~km}^{2} \mathrm{yr}^{-1}\left(0.27 \% \mathrm{yr}^{-1}\right)$. After 1950 , atmospheric $\mathrm{CO}_{2}$ concentrations, nitrogen deposition, and air temperatures increased at rates 2-3 times higher than in the first half of $20^{\text {th }}$ century. Their respective rates were $0.02^{\circ} \mathrm{C} \mathrm{yr}^{-1}$, $0.1 \mathrm{Tg} \mathrm{N} \mathrm{yr}^{-1}$, and $1.11 \mathrm{ppm} \mathrm{yr}^{-1}$ for the period $1950-2000$. To the contrary, the rate of land cover conversion slowed down, with the agriculture coverage declining at a rate of $7000 \mathrm{~km}^{2} \mathrm{yr}^{-1}\left(0.18 \% \mathrm{yr}^{-1}\right)$. Forest and grassland areas expanded with the rates of $5800 \mathrm{~km}^{2} \mathrm{yr}^{-1}\left(0.12 \% \mathrm{yr}^{-1}\right)$ and $1100 \mathrm{~km}^{2} \mathrm{yr}^{-1}\left(0.24 \% \mathrm{yr}^{-1}\right)$, respectively.

Overall changes in land cover of Europe (9.32 million $\mathrm{km}^{2}$ ) were relatively small over the 20th century. The fraction of European forests shrank by approximately $3 \%$ before 1950 and expanded thereafter by the same amount. Proportion of agricultural land increased by $5 \%$ in the first half of 20th century and dropped by $4 \%$ after 1950 . Changes in the fractions of grasslands were in the order of $1-2 \%$ over the first and the second halves of the 20th century.

\subsection{Carbon balance and its attribution}

Until approximately 1960, the average carbon balance of European terrestrial ecosystems estimated by all models was close to zero (Fig. 2). From the 1960-70's onwards, European ecosystems were sequestering atmospheric $\mathrm{CO}_{2}$ at an average rate of $85 \mathrm{TgC} \mathrm{yr}^{-1}$ in 1980 's, $108 \mathrm{TgC} \mathrm{yr}^{-1}$ in 1990's, and $114 \mathrm{TgC} \mathrm{yr}^{-1}$ in 2000-2007. These estimates are subject to considerable interannual variability $(69,79$, and $54 \mathrm{Tg} \mathrm{C} \mathrm{yr}^{-1}$ respectively; Table 3, Fig. 2), as was also shown earlier (Zaehle et al., 2007; Vetter et al., 2008). The respective rates of changes in atmospheric $\mathrm{CO}_{2}$ concentrations were $1.38 \mathrm{ppm} \mathrm{yr}^{-1}$ in 1980 's, $1.39 \mathrm{ppm} \mathrm{yr}^{-1}$ in 1990's, and $1.71 \mathrm{ppm} \mathrm{yr}^{-1}$ in 2000-2007. The respective rates of changes in nitrogen deposition were $0.06 \mathrm{Tg} \mathrm{N} \mathrm{yr}^{-1}$, $0.09 \mathrm{Tg} \mathrm{Nyr}^{-1}$, and $0.09 \mathrm{Tg} \mathrm{Nyr}^{-1}$. In the second half of the 20th century European ecosystems sequesterd carbon at a rate of $56 \mathrm{TgC} \mathrm{yr}^{-1}$ (mean of four models for 1951$2000)$ with strong interannual variability $\left( \pm 88 \mathrm{TgC} \mathrm{yr}^{-1}\right.$, average across models) and substantial inter-model uncertainty $\left( \pm 39 \mathrm{TgC}^{-1}{ }^{-1}\right)$. Below we describe the effect of environmental drivers on land carbon uptake after 1950 and the pools in which carbon was accumulating. 
Table 3. Mean carbon balance of Europe from different land-based data compilation and model simulations. The inter-model uncertainty is quantified as the standard deviation of the modeled average carbon uptake for a given period. The inter-annual variability is the inter-model mean of the variability of the annual means for each model.

\begin{tabular}{|c|c|c|c|c|}
\hline & 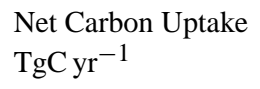 & $\begin{array}{l}\text { Uncertainty } \\
\mathrm{TgC}_{\mathrm{yr}}{ }^{-1}\end{array}$ & $\begin{array}{l}\text { Area } \\
10^{6} \mathrm{~km}^{2}\end{array}$ & $\begin{array}{l}\text { Time } \\
\text { Period }\end{array}$ \\
\hline Modeled (this study, & 56 & \pm 39 inter-model difference; \pm 88 inter-annual variability & 9.32 & $1951-2000$ \\
\hline \multirow{4}{*}{$\left.\mathrm{Clim}+\mathrm{CO}_{2}+\mathrm{LUC} / \mathrm{N}\right)$} & 100 & \pm 45 inter-model difference; \pm 85 inter-annual variability & & 1980-2007 \\
\hline & 85 & \pm 26 inter-model difference; \pm 69 inter-annual variability & & 1980-1989 \\
\hline & 108 & \pm 74 inter-model difference; \pm 79 inter-annual variability & & 1990-1999 \\
\hline & 114 & \pm 19 inter-model difference; \pm 54 inter-annual variability & & 2000-2007 \\
\hline Modeled (Vetter et al., 2008) & 157 & 70-230 inter-model range & 9.32 & 1980-2005 \\
\hline Modeled (Zaehle et al., 2007) & 30 & $-45-106$ inter-annual variability range & 3.7 & 1990-1999 \\
\hline (Schulze et al., 2009) & 235 & \pm 50 & 9.29 & $2000-2005$ \\
\hline (Janssens et al., 2003) & 111 & \pm 280 & 10.4 & unspecified \\
\hline
\end{tabular}

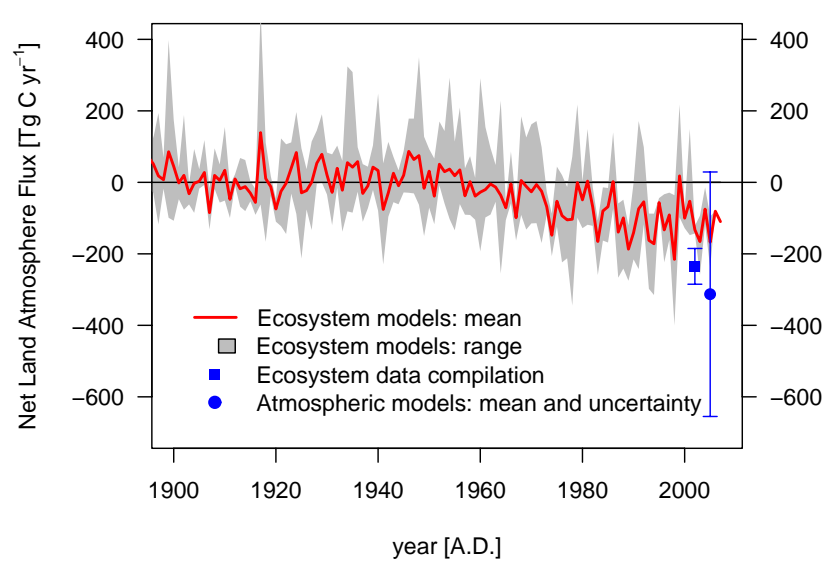

Fig. 2. European net land-atmosphere carbon flux in 20th century estimated with ecosystem models. Red line is an average value estimated with three ecosystem models (BIOME-BGC, ORCHIDEE, and JULES). The gray shaded area depicts the models' range. Modeled carbon balance at the end of the 20th century is lower than the mean value of carbon balance from the ecosystem model compilation (blue square) or the inverse estimations of atmospheric models (blue dot) (Schulze et al., 2009) reported as an average for 20002005.

\subsubsection{Effects of environmental drivers}

The overall effect of rising carbon dioxide, changing climate, as well as land cover conversion or rising nitrogen on the average net carbon uptake for 1950-2000 was positive in all models, implying a net storage of $25-94 \mathrm{TgC}^{-1}$. All models indicated that European terrestrial ecosystem sequestered carbon as a result of the interactions between several environmental factors (Fig. 3). The total simulated carbon sink in Europe was significantly different from zero and similar between JULES, BIOME-BGC, and O-CN models - at least if one considers only the European-wide mean values and their interannual variability. ORCHIDEE simulated response of NEE to all factors, which was not significantly different from zero.

In BIOME-BGC and O-CN, which account for carbonnitrogen dynamics, the European carbon sink was the result of $\mathrm{CO}_{2}$ fertilization and nitrogen deposition, as well as interactions between these factors. $\mathrm{CO}_{2}$ fertilization of ecosystems was the most important factor responsible for the net carbon uptake simulated in models only accounting for the carbon cycle. This $\mathrm{CO}_{2}$ fertilization effect more than offset the negative effects of land cover conversion on terrestrial carbon storage as simulated by ORCHIDEE and strengthened the positive effect of land cover conversion in JULES.

Changes in climate (mostly due to rising temperatures) resulted in a land carbon source in the two models including for carbon cycle only, due to high soil carbon losses (see Fig. 4). Responses of net carbon flux to changes in climate were significantly different from zero in simulations with JULES and ORCHIDEE, but not in BIOME-BGC and O$\mathrm{CN}$ simulations. Climate had hardly any effect on the carbon balance in models accounting for carbon-nitrogen dynamics (Fig. 3). Models with carbon-nitrogen dynamics simulated very small net carbon uptake (3-6 $\mathrm{Tg} \mathrm{Cyr}^{-1}$ ), while models with carbon cycle only suggest a net carbon source (30$80 \mathrm{TgC}^{-1}$ ) during 1950-2000. Changes in climate during this time period were mostly associated with rising temperatures, which lead to increases in both $\mathrm{CO}_{2}$ release as well as soil nitrogen mineralization from accelerated soil organic matter decomposition. Because nitrogen is the major limiting nutrient for plant growth in high and mid latitudes, more available nitrogen in soil enhances plant $\mathrm{CO}_{2}$ uptake, which compensates for the higher $\mathrm{CO}_{2}$ emissions from soil decomposition. This is exactly the case in the responses of models with carbon-nitrogen dynamics to changes in climate. Models with carbon cycle only lack this compensation mechanism and respond to rising temperatures with increased $\mathrm{CO}_{2}$ release only. 


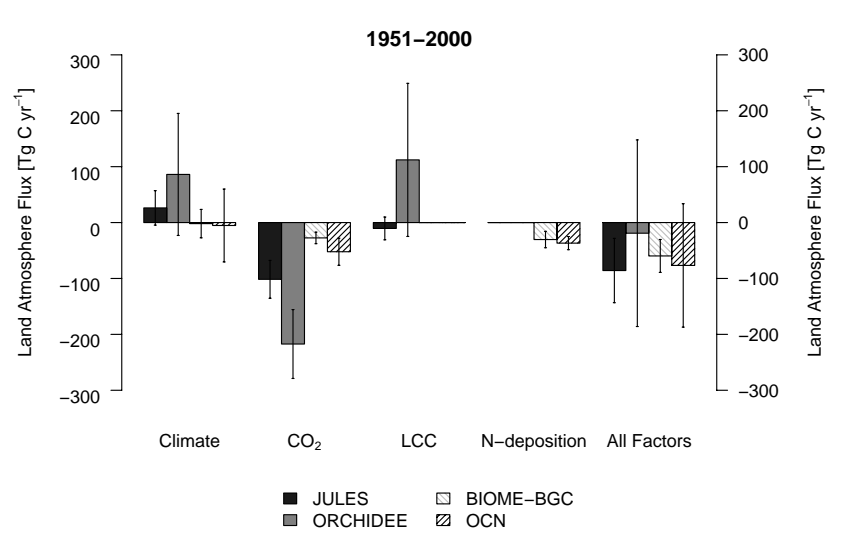

Fig. 3. Changes in European land-atmosphere carbon fluxes over the period 1951-2000 attributed to climatic changes, increases in atmospheric $\mathrm{CO}_{2}$, land-cover changes (LCC), nitrogen deposition, and three factors combined. Land-atmosphere carbon flux was estimated with four ecosystem models such as JULES, ORCHIDEE, BIOME-BGC, and O-CN. Two models including N cycle (solid shaded bars) show better agreement than the models including land cover conversion (bars with diagonal stripes). Each bar depicts the annual change in terrestrial C storage averaged over 1951-2000, with the error bars denoting the standard deviation of the change.

Increasing $\mathrm{CO}_{2}$ enhanced net land carbon uptake and it was significantly different from zero in all models. The response of land ecosystems to rising $\mathrm{CO}_{2}$ was considerably larger in models without nitrogen dynamics (110$\left.230 \mathrm{TgC} \mathrm{yr}^{-1}\right)$ than in models with nitrogen dynamics (30$65 \mathrm{TgC}^{-1} \mathrm{r}^{-1}$. Land cover conversion had opposite net effects on the carbon balance simulated by ORCHIDEE and JULES. Land cover changes in JULES led to a small net carbon uptake $\left(15 \mathrm{TgC}^{-1}\right)$, which was not significantly different from zero. In ORCHIDEE land ecosystems responded with the substantial net release of carbon $\left(115 \mathrm{TgC} \mathrm{yr}^{-1}\right)$. Nitrogen deposition enhanced ecosystem net carbon uptake between 30 and $37 \mathrm{TgC} \mathrm{yr}^{-1}$. Both models with carbonnitrogen dynamcs had consistent responses to rising nitrogen deposition.

\subsubsection{Changes in carbon pools}

In land ecosystems, carbon can accumulate in soil or in vegetation or in both. Our study points to changes in the growth of woody vegetation as an important contributor to the European carbon sink (Fig. 4). Three out of four models reported that vegetation accumulated most of the additional carbon. Model simulations of ORCHIDEE, BIOME-BGC, and $\mathrm{O}-\mathrm{CN}$ indicated that carbon was accumulated in both vegetation and soil. In these three models vegetation was a stronger sink $\left(20,60,60 \mathrm{TgC} \mathrm{yr}^{-1}\right.$ respectively) than soil $\left(10,5,25 \mathrm{TgC} \mathrm{yr}^{-1}\right.$ respectively). JULES simulations indicated that soil stored all additional carbon $\left(100 \mathrm{TgC} \mathrm{yr}^{-1}\right)$, while vegetation was a small carbon source $\left(4 \mathrm{TgC}^{-1}\right)$.
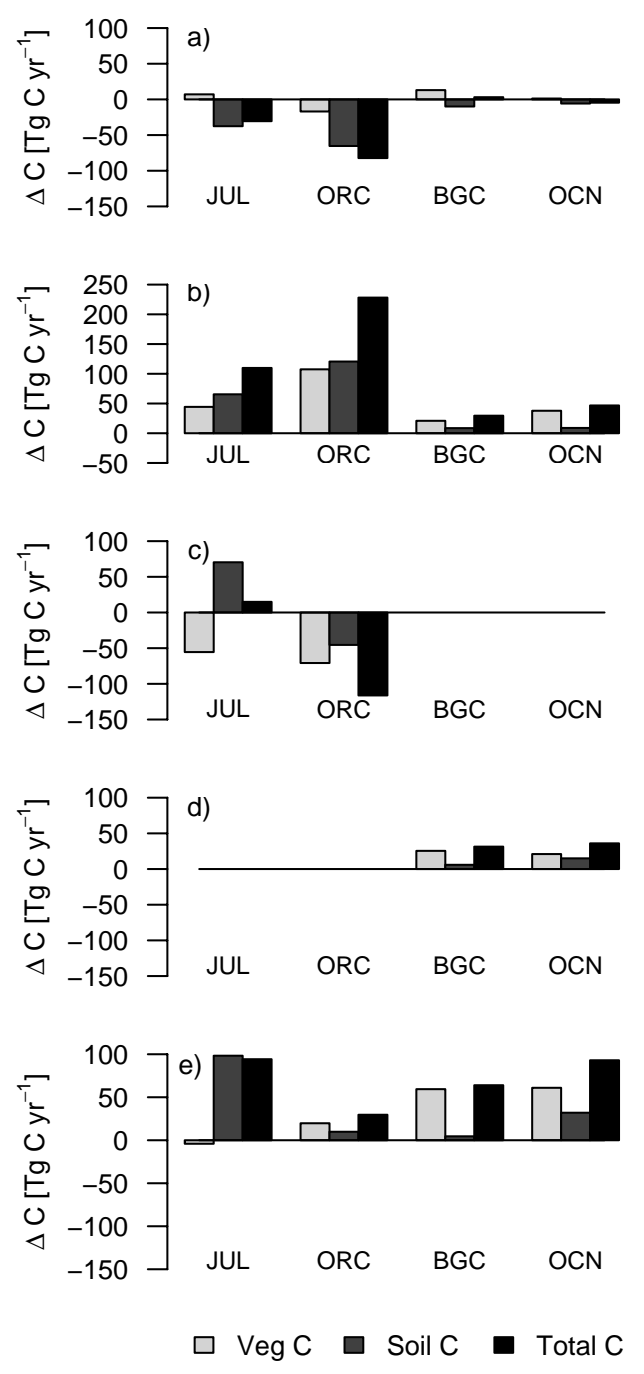

Fig. 4. Changes in soil and vegetation carbon pools in response to climate (a), atmospheric carbon dioxide concentration (b), land cover change (c), atmospheric nitrogen deposition (d), and three factors together (e). Each bar represents annual change in carbon stock averaged over 1951-2000. Carbon stocks are estimated with JULES, ORCHIDEE, BIOME-BGC, and O-CN.

The differences in ecosystem pools accumulating carbon stem from differences in ecosystem responses to individual environmental drivers. In the model simulations with changing climate only, soil carbon pool was significantly affected in all models (Fig. 4). In JULES and ORCHIDEE, rising temperatures led to soil carbon releases that averaged at 37 and $65 \mathrm{TgC} \mathrm{yr}^{-1}$ respectively over the period $1951-$ 2000. Soil carbon loss was not compensated for by small vegetation carbon gain in JULES $\left(7 \mathrm{TgC} \mathrm{yr}^{-1}\right)$. Soil carbon loss was enhanced by vegetation carbon loss in ORCHIDEE, BIOME-BGC, and O-CN accounted for the feedback of increasing temperatures on increased nitrogen mineralization and therefore improved plant nutrition. Therefore 
these models simulated a stronger vegetation carbon gain (13 and $3 \mathrm{TgC} \mathrm{yr}^{-1}$ respectively) and weaker soil carbon loss (10 and $5 \mathrm{Tg} \mathrm{C} \mathrm{yr}^{-1}$ respectively), resulting in approximately zero carbon balance. Changes in vegetation carbon stocks were not statistically significantly different in JULES and BIOME-BGC simulations for climate change experiment. Changes in vegetation stocks of all other model combinations were statistically different from each other and from zero. Changes in total carbon stocks simulated by BIOMEBGC were not statistically significant from zero for climate change scenarios, respectively.

All models agreed that rising atmospheric $\mathrm{CO}_{2}$ concentrations lead to carbon accumulation in both soil and vegetation. In JULES and ORHIDEE less carbon was accumulated in vegetation (44 and $107 \mathrm{TgC} \mathrm{yr}^{-1}$ respectively) than in soil (65 and $120 \mathrm{TgC} \mathrm{yr}^{-1}$ respectively). The increase in carbon storage in response to $\mathrm{CO}_{2}$ outweighed the decrease due to climate change in all models as previously found in JULES by Harrison et al. (2008). Conversely, BIOME-BGC and $\mathrm{O}-\mathrm{CN}$ simulated higher increase in carbon storage in vegetation (21 and $40 \mathrm{TgC} \mathrm{yr}^{-1}$ respectively) than in the soil $\left(8 \mathrm{TgC} \mathrm{yr}^{-1}\right)$. These differences are related to various representations of tree mortality and soil carbon turnover rates in the models. Changes in total carbon stocks in this experiment have been significantly different from zero and from each other for individual models.

In the simulations with land cover conversion, both JULES and ORCHIDEE simulated a similar rate of carbon loss due to the removal of vegetation (55 and $70{\mathrm{TgC} \mathrm{yr}^{-1}}^{-1}$, respectively). The models disagreed strongly on the fate of carbon in the soil pool. While JULES simulated substantial soil carbon gain $\left(70 \mathrm{TgC} \mathrm{yr}^{-1}\right)$, which more than offset the rate of carbon lost by vegetation removal, ORCHIDEE simulated net soil carbon losses $\left(45 \mathrm{Tg} \mathrm{C} \mathrm{yr}^{-1}\right)$. Changes in total carbon stocks simulated by JULES were not significantly different from zero in response to land use changes.

\subsubsection{Spatial patterns of NEE and NBP (1951-2000)}

The models generate substantially different patterns of net carbon sources and sinks when averaged over 50 years (Fig. 5). BIOME-BGC shows rather homogeneous carbon sink over Europe with several patches of high carbon sink where high nitrogen deposition rates overlap with forests. JULES and ORCHIDEE have very heterogeneous distributions of carbon sources and sinks as a result of various responses to the land cover conversion and harvest decomposition in these model simulations. If we do not account for the effect of land-cover conversions in these models, the NEE patterns are rather homogeneous in both models and similar to the estimates of BIOME-BGC (suppl. Fig. S1), even though absolute NEE values in these models are substantially higher than in BIOME-BGC.

The aforementioned uncertainties in the simulation of harvest as well as in where and how fast carbon from harvested biomass is released back to the atmosphere, cause different patterns of NBP (Fig. 6). ORCHIDEE simulates a large carbon source in Eastern Europe, which patterns seem to coincide with areas of continuing agricultural expansion.

\section{Discussion}

\subsection{Carbon balance of European ecosystems}

Previous observation-based (Schulze et al., 2009; Janssens et al., 2003) and modeling studies (Vetter et al., 2008; Zaehle et al., 2007) suggest a substantial net carbon uptake in European ecosystems over the last decades. Although the comparable estimates of land-atmosphere carbon fluxes from this study confirm ecosystem carbon uptake, our estimates are lower, than those based on extrapolated field studies and previous model estimates (Table 3). The most recent bottomup estimate of the European net carbon uptake from data compilation is $235 \pm 50 \mathrm{TgC} \mathrm{yr}^{-1}$ for 2000-2005 (Schulze et al., 2009). This estimate is higher than our estimate of $114 \mathrm{TgC} \mathrm{yr}^{-1}$ for $2000-2007$ as well as the previous estimate of $111 \pm 280 \mathrm{TgC} \mathrm{yr}^{-1}$ from data compilation for unspecified period (Janssens et al., 2003). High carbon uptake estimated for forests and grasslands as well as almost negligible carbon source for croplands $\left(33 \mathrm{TgC} \mathrm{yr}^{-1}\right)$ are the possible reasons for high carbon uptake estimated by (Schulze et al., 2009). Croplands emitted $300{\mathrm{TgC} \mathrm{yr}^{-1}}^{-1}$ in the previous compilation report (Janssens et al., 2003).

Estimates of the European carbon balance based on the inversion of atmospheric $\mathrm{CO}_{2}$ measurements by atmospheric transport modeling give a wide range of the net carbon storage rates. The most recently published estimate of landatmosphere flux from atmospheric inversions averages at $-313 \pm 342 \mathrm{TgC} \mathrm{yr}^{-1}$ (Schulze et al., 2009), with the uncertainty estimate being the quadratic sum of the spread between individual inversions and the uncertainties in each inverse estimate. The earlier inverse estimates summarized by Janssens et al. (2003) are at a comparable level, suggesting a net car-

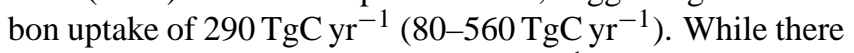
is a substantial difference of $213 \mathrm{TgC} \mathrm{yr}^{-1}$ between the atmospheric and ground-based modeled estimates of mean carbon NEE for 2000-2007, the ground-based model based estimate easily falls into the range of the atmospheric inversions.

Based on the results of seven vegetation models, Vetter et al. (2008) estimated the net carbon balance of European ecosystems to be between 70 and $230 \mathrm{TgC} \mathrm{yr}^{-1}$. This carbon balance was calculated as a mean of annual NEP for 1980-2005 from models' simulations driven by REMO climate data and did not include effects of land cover conversion, but nitrogen deposition in BIOME-BGC model. Zaehle et al. (2007) used one vegetation model (LPJ) to estimate the effect of land-cover changes, climate, and $\mathrm{CO}_{2}$ on the Western European terrestrial carbon balance. The resulted 

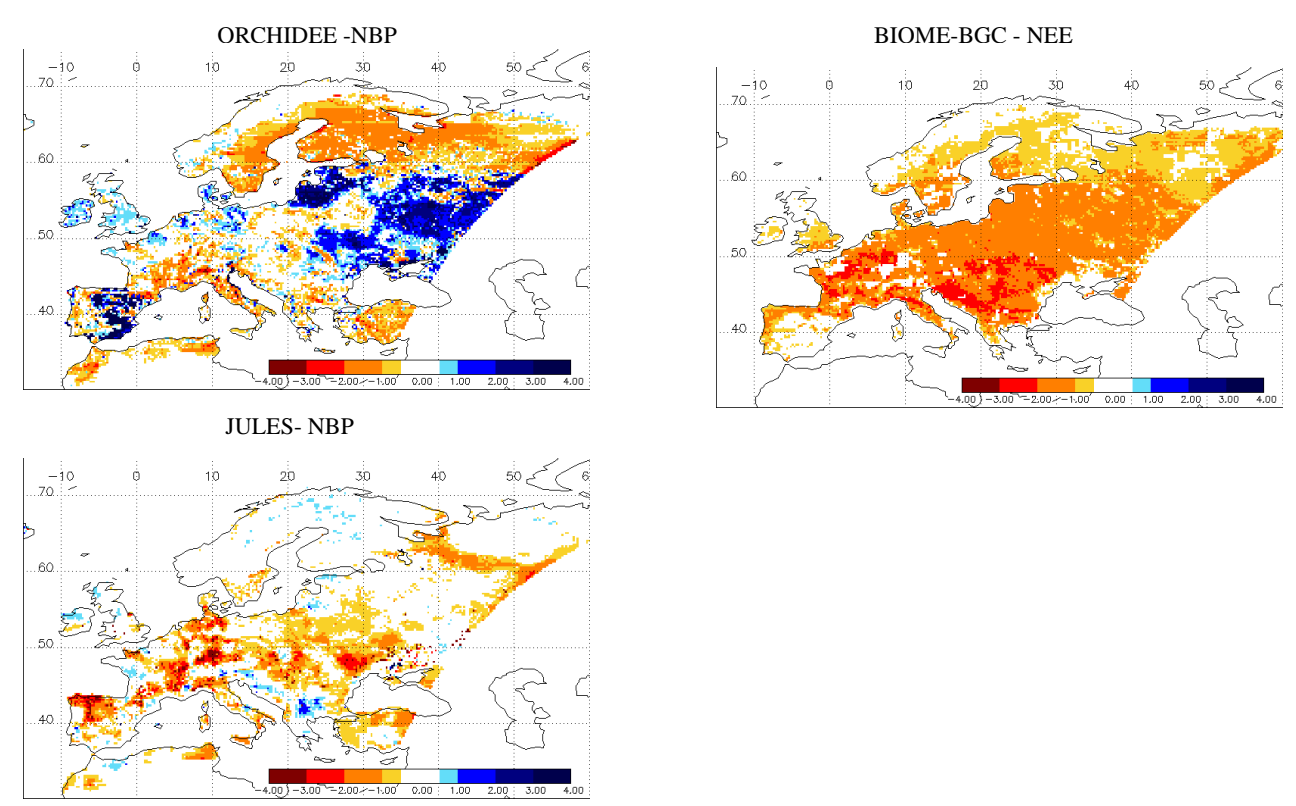

Fig. 5. Cumulative net land-atmosphere fluxes ( $\mathrm{kgC}$ per 50 years, sum over 1951-2000) estimated with three ecosystem models. NBP for JULES and ORCHIDEE refer to a simulation accounting for climatic changes, increases in atmospheric $\mathrm{CO}_{2}$ concentrations, and land use changes $\left(\mathrm{Clim}+\mathrm{CO}_{2}+\mathrm{LUC}\right)$. The NEE simulated by BIOME-BGC is driven by climatic changes, increases in $\mathrm{CO}_{2}$ and atmospheric nitrogen deposition $\left(\mathrm{Clim}+\mathrm{CO}_{2}+\mathrm{N}\right)$. Areas colored in different shades of red and yellow are carbon sink. Areas colored in different shades of blue are carbon source.

net carbon uptake of $30 \mathrm{TgC} \mathrm{yr}^{-1}$ is compatible with our estimates given the substantially smaller spatial domain.

\subsection{Attribution}

What are the processes driving the European land net carbon uptake? Previous observation-based studies analyzed contributions of land cover types or forest processes to this sink. Schulze at al. (2009) and Janssens et al. (2003) consistently suggest that there is a net carbon uptake in the European ecosystems mostly because of carbon gains in forests and grassland soils, which are partly offset by losses of carbon from croplands and peat soils. Schulze at al. (2009) also quantify land use change as an additional carbon sink (discussed below). As we have discussed the effect of climate and climate variability in a previous paper (Vetter et al., 2008), here we focus our discussion on the effects of the other transient changes in driving forces of the terrestrial carbon balance.

Large differences in responses of the carbon balance to changes in single drivers between models (Fig. 3) are related to inclusion/omission of carbon-nitrogen interactions in the models and differences in modeled processes related to land use change. Simulated ecosystem responses were more consistent for the two models accounting for carbon-nitrogen dynamics than for the two models including carbon cycle and the effects of land use change. The latter is because the carbon-nitrogen interactions are easier to upscale than the carbon- land-use change interactions. Below we discuss modeled responses of land-atmosphere carbon flux to individual environmental factors and their plausibility in detail.

\subsubsection{Atmospheric $\mathrm{CO}_{2}$ concentrations}

Because very few studies (Hamilton et al., 2002) have attempted to quantify the effect of elevated $\mathrm{CO}_{2}$ on NEE, we focus the discussion on the response of NPP, which is the primary cause for changes of the modeled net carbon uptake in response to increase in atmospheric $\mathrm{CO}_{2}$. This comparison is challenging because experimental designs of field and model experiments are not the same. In the model experiment terrestrial ecosystems have been exposed to continuously rising $\mathrm{CO}_{2}$ over 200 years. Field experiments impose a 6-10 years "step" increase of $\mathrm{CO}_{2}$ to at least $200 \mathrm{ppm}$ above recent ambient levels of atmospheric $\mathrm{CO}_{2}$. The modeled response of European NPP to $100 \mathrm{ppm}$ increase in atmospheric $\mathrm{CO}_{2}$ concentrations (from $287 \mathrm{ppm}$ in 1870 to $387 \mathrm{ppm}$ in 2007) was $10 \%$ (BIOME-BGC), $20 \%$ (O-CN and JULES), and $36 \%$ (ORCHIDEE). Above-ground dry matter production increased $20 \%$ on average for $29 \mathrm{C} 3$ species grown in six different Free Air $\mathrm{CO}_{2}$ Enrichment (FACE) experiments (Ainsworth and Long, 2005). The response of the aboveground dry matter production reported in field studies ranges from $10 \%$ for $\mathrm{C} 3$ grasses to $28 \%$ for forests to $190-200 \mathrm{ppm}$ increase of $\mathrm{CO}_{2}$ (from ambient $\mathrm{CO}_{2}$ concentration in 1990's of $360 \mathrm{ppm}$ to maximum $550-600 \mathrm{ppm}$ of $\mathrm{CO}_{2}$ ). Trees grown under nutrient limitations had an insignificant $14 \%$ stimulation in above-ground biomass accumulation (Ainsworth and 

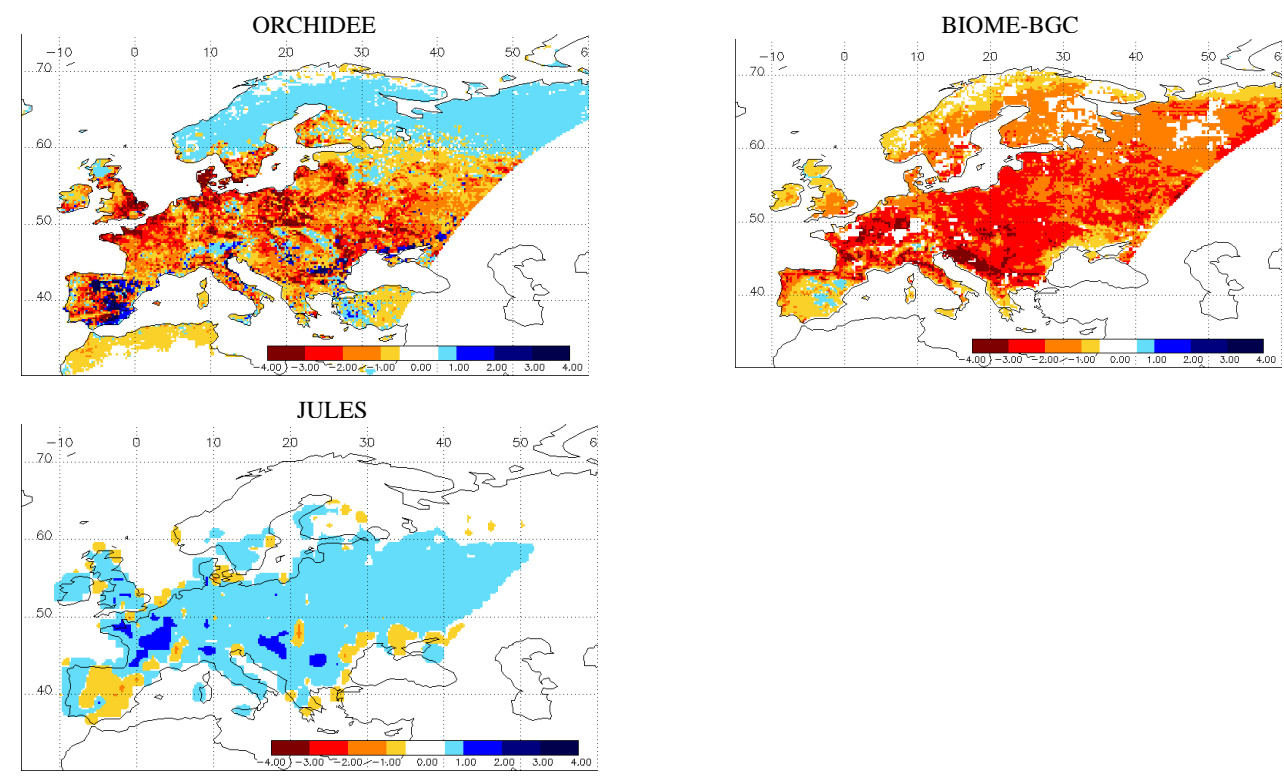

Fig. 6. Cumulative land-atmosphere fluxes ( $\mathrm{kgC}$ per 50 years, sum over 1951-2000) resulted from land use conversion and rising nitrogen deposition. These fluxes are calculated as difference between NEE from two model experiments $\mathrm{Clim}+\mathrm{CO}_{2}+\mathrm{LUC}$ and $\mathrm{Clim}+\mathrm{CO} 2$ for ORCHIDEE and JULES and as difference between $\mathrm{Clim}+\mathrm{CO}_{2}+\mathrm{N}$ and $\mathrm{Clim}+\mathrm{CO}_{2}$ for BIOME-BGC. Areas colored in different shades of red are carbon sink; areas colored in different shades of blue are carbon source.

Long, 2005). Field studies suggest that plant growth response to elevated $\mathrm{CO}_{2}$ likely slows over time, probably because of reduced nitrogen availability (Hungate et al., 2006). The latter effect explains weaker response to increasing $\mathrm{CO}_{2}$ in BIOME-BGC or O-CN than in ORCHIDEE or JULES.

\subsubsection{Atmospheric nitrogen deposition}

Soil nitrogen status as well as frequency and intensity of nitrogen additions play important roles in the ecosystem's response to increased deposition of atmospheric nitrogen. In field experiments $1-1000 \mathrm{kgN} \mathrm{ha}^{-1}$ is added one-two times per year. These frequencies and magnitudes of nitrogen addition cannot be directly compared to the gradual increase in nitrogen deposition from atmosphere $\left(2-28 \mathrm{kgN} \mathrm{ha}^{-1} \mathrm{yr}^{-1}\right)$ in "undisturbed" ecosystem such as those represented in our numerical simulations. Between 1860 and 2007 the modeled European NPP increased on average by $7.5 \%$ in BIOME$\mathrm{BGC}$ and by $16 \%$ in $\mathrm{O}-\mathrm{CN}$ in response to the rise in average nitrogen deposition rate of $5 \mathrm{kgNha}^{-1} \mathrm{yr}^{-1}$. This response seems plausible given the evidence from field studies. Observational studies suggest that aboveground NPP increased by approximately 28-29\% in the cross-biome analyses of terrestrial plants (LeBauer and Treseder, 2008; Elser et al., 2007) in fertilizer experiments. Taking into account uncertainties about the response of belowground NPP which might compensate for the increase in aboveground growth, this estimate gives the upper bound of the likely response of total net primary production as simulated by the models. The average biomass response to low nitrogen additions of approximately
$10-50 \mathrm{kgN} \mathrm{ha}^{-1} \mathrm{yr}^{-1}$ was considerably weaker for woody than for herbaceous plants or $24.6 \%$ and $50 \%$ respectively (Xia and Wan, 2008). In opposite, modeled NPP response of herbaceous plants $(6 \%)$ to nitrogen additions was weaker than for deciduous forests $(10 \%)$, but stronger than for coniferous forests $(3 \%)$ in the BIOME-BGC model. Differences in forest responses can be explained by different average rates of nitrogen deposition over coniferous and broadleaf forests ( 4 and $11 \mathrm{kgN} / \mathrm{ha} / \mathrm{yr}$ respectively). Modeled NPP response of herbaceous vegetation is underestimated, because average nitrogen depositions over herbaceous vegetation and deciduous forest were comparable $\left(6-10 \mathrm{kgC} \mathrm{ha}^{-1} \mathrm{yr}^{-1}\right.$ and $\left.11 \mathrm{kgC} \mathrm{ha}^{-1} \mathrm{yr}^{-1}\right)$. This underestimation is most likely responsible for lower European NPP response to rising nitrogen deposition in BIOME-BGC model as compared to $\mathrm{O}$ CN.

A number of recent studies (Magnani et al., 2007; Sutton et al., 2008; de Vries et al., 2009) analyzed the response of net carbon storage in forest ecosystems to nitrogen deposition using manipulation experiments and other streams of data. The most recent study (de Vries et al., 2009) reports the response of $5-75 \mathrm{kgC} / \mathrm{kgN}$ for both forests and heathlands after discounting for potential interaction effects due to concomitant changes in other environmental factors. The mean responses of BIOME-BGC ( $43 \mathrm{kgC} / \mathrm{kg} \mathrm{N})$ and $\mathrm{O}-\mathrm{CN}$ $(38 \mathrm{kgC} / \mathrm{kg} \mathrm{N})$ fall well into this range. 


\subsubsection{Land cover conversion}

The estimates of changes in the net land-atmosphere carbon flux associated with land cover conversion and management depend on the accuracy of the estimates of past land-use changes, the simulated biomass of the vegetation which is replaced, and on the ecosystem response to the change in land use type. Consistent data of historical land use changes are very sparse at a continental scale, so that substantial uncertainty is inherent in any backward projection of land-use patterns (Ramankutty and Foley, 1999; Hurtt et al., 2006). These data typically only record net changes in a land-cover type within a region. They do not specify co-occurring deand reforestation of this region. Because these two parallel processes determine the net carbon flux due to land-use changes, our model results provide a low bound of the effect of land-use changes on the carbon balance.

In 1950-2000 conversions of croplands into forests and grasslands prevailed in Europe (Fig. 1). Based on metaanalysis of experimental studies Guo and Gifford (2002) suggested increase in soil carbon after changes from crop to pasture or to forest plantation $(+18-19 \%)$ and from crop to forest $(+54 \%)$. The change in soil carbon stock as a result of land cover conversion depends on the sizes of the soil carbon pools of the land cover types at equilibrium. Cropland soils have lower carbon stocks than grasslands, whereas forest and grassland soils have similar pool sizes (Guo and Gifford, 2002). Although JULES and ORCHIDEE models are able to simulate such differences, models had substantially different responses to land cover conversion (Fig. 3). JULES simulated a small net carbon uptake in land ecosystems $\left(15 \mathrm{TgC} \mathrm{yr}^{-1}\right)$. In ORCHIDEE ecosystems responded with a substantial net release of carbon $\left(115 \mathrm{TgC} \mathrm{yr}^{-1}\right)$. Using data compilation Schulze et al. (2009) estimated a net sink of $60 \mathrm{Tg} \mathrm{C} \mathrm{yr}^{-1}$ associated with soil carbon gain and loss following land use change in Europe. This discrepancy results from uncertainty in the fate of residuals remaining in the ecosystem upon conversion and in the representation of the differences between soil carbon stocks of different landuse types in the model. The amount of carbon which enters the soil carbon pools as residuals increases the potential for longer-term increases in soil organic matter with time. We suggest that improved understanding of the fate of carbon is response to land-use change is a key requirement for future research.

ORCHIDEE suggests that vegetation is the major store of extra carbon, while the results of JULES imply that carbon storage in soils dominates. Model simulations give different answers because of different model algorithms. In ORCHIDEE, forests re-grow on abandoned agricultural areas following the land cover conversion prescribed in this study. Regrowing forests first accumulate carbon in wood, which only later propagates into increases in soil carbon due to the reduced carbon export in forests relative to highly managed cropland ecosystems. Therefore, the vegetation pool con- tributes stronger to the carbon storage in the ORCHIDEE model. In JULES, while net conversion rates were used as given from in the modeling protocol, the internally simulated vegetation dynamics (see Methods section) resulted in a different fate of the land from cropland abandonment. In JULES agricultural contraction after 1950 implies grassland replace cropland with a longer timescale for eventual succession by forest. The major difference between these two vegetation types in JULES is that crops are regularly harvested, while grasslands are not. Once grassland replaces cropland all aboveground carbon enters soil pool after litter fall and soil carbon increases in this model, whereas the vegetation carbon pool hardly changes. Next generation vegetation dynamics models which explicitly treat disturbance, succession and age-structure are required to more realistically quantify this response.

\subsection{Uncertainties in the modeled carbon balance}

The present study provides the latest of various model assessments in which we addressed various uncertainties in modeled components of carbon balance. We have previously assessed ability of the models to replicate the ecosystem responses to regional gradients in climate (Jung et al., 2007a) and large scale climate anomalies (Vetter et al., 2008), identifying biases of individual models and key uncertainties in regional scale carbon balance from input drivers (Jung et al., 2007b). Among input drivers climate data has been identified as the dominant source of uncertainty (Jung et al., 2007b). The ecosystem models systematically underestimated the decrease in gross photosynthetic uptake from temperate to boreal forest sites (Jung et al., 2007a). This underestimation was attributed to insufficiently accounting for nitrogen limitation that acts mainly on leaf area and thus light absorption. An experiment combining ecosystem models with atmospheric transport models indicated that modeled $\mathrm{CO}_{2}$ concentrations were biased at the measurements stations, which are located in large agricultural regions of Hungary (Hegyhatsal station) and the Netherlands (Cabaw station) (U. Karstens, personal communication, 2009). These biases point to difficulties in capturing the heterogeneity of agricultural landscapes and in modeling cropland carbon dynamics influenced by land management.

Change in land management could be the other reason behind carbon balance change, which we did not account for in this study. Discrepancy between timber harvest and forest productivity has been discussed as a possible reason behind carbon accumulation in European ecosystems. Analysis of forest inventories (Nabuurs et al., 2003; Ciais et al., $2008 \mathrm{~b}$ ) points to forests as a potential sink of carbon. These studies suggest that the slow increase in timber harvests in comparison to the rapid increase in forest ecosystem productivity is the key driving factor behind this trend, causing forest tree biomass in the EU-15 plus Norway and Switzerland to accumulate 2.3 Pg of carbon between 1950 and 2000 . 
NPP of needleaf forests from three ecosystem models used in this study was lower in than from forest inventory based model (Tupek et al., 2010), which included forest age and management effects on NPP. This comparison indicates that forest carbon uptake may have been underestimated in this study. A modeling study analyzing forest inventories, forest use statistics, climatic changes, and $\mathrm{CO}_{2}$ increases suggests that the effects of changes in forest management, forest area and age-structure explain 50\% of the increase in forest biomass for EU-25 (Zaehle et al., 2006). Although past landmanagement changes further affect soil carbon inputs or soil carbon turnover times and their effect is poorly quantified for large regions (Zaehle et al., 2007). Model simulations show that alternative assumptions about crop management and the fate of residues notably alter the soil carbon stock and trajectories following conversion (Bondeau et al., 2007; Smith et al., 2005, 2006). These factors offset temperature-related soil carbon losses from simulated in this study. Because of a lack of data to parameterize land management changes over time, these effects have not been considered in the present study.

The interactions between individual driving forces of carbon balance complicate accurate attribution of the simulated trends to these forces. For instance, compensating effect of increasing nitrogen availability in soil due to enhanced atmospheric nitrogen deposition versus decreased nitrogen availability in soil due to fertilizing effect of $\mathrm{CO}_{2}$ on plant growth, as discussed by Churkina et al. (2009) and Zaehle et al. (2010). None of the models in this study can yet represent all of the forcings we consider, and so we are not able to quantify the effect of possible interactions between nitrogen limitation and land-use change. Disentangling these effects requires multi-factorial model simulations able to respond to the non-linear factor interactions. For instance by running a simulation with only the factor of interest varying or by calculating the difference between two simulations, one with all factors and a second, in which all but the factor of interests vary with time. Doing so has not been feasible within the present analyses. Hence, our results allow identifying the relative importance of the driving forces, but the absolute values need to be treated with caution. Interaction effects may shift individual contribution up or down by a few percent, depending on the way the individual contribution has been calculated.

Here we did not investigate uncertainties related to the lateral carbon fluxes driven by soil erosion (Quinton et al., 2010) or by relocation of forest and crop harvests (Ciais et al., 2008a). None of the models here was capable to simulate soil erosion. JULES and ORCHIDEE simulated forest and crop harvest and their decomposition. None of them however simulated harvest relocation here.

\section{Conclusions}

The model projections consistently suggest that the European ecosystems acted as net carbon storage during the period 1951-2007. The models suggest a slight increase in the decadal mean uptake from $85 \mathrm{Tg} \mathrm{Cyr}^{-1}$ in the $1980 \mathrm{~s}$ to $114 \mathrm{Tg} \mathrm{Cyr}^{-1}$ in the 2000s. Increases in atmospheric $\mathrm{CO}_{2}$ enhanced the carbon uptake across all models. Models accounting for carbon-nitrogen dynamics consistently simulated a weaker response to increases in atmospheric $\mathrm{CO}_{2}$ than models without nitrogen cycle included. The positive response of net carbon uptake to increased atmospheric input of reactive nitrogen only partly compensated the difference in uptake between two model types. In 1951-2000 land cover conversion increased European carbon stock in vegetation. Large uncertainty exists however in its impact on soil carbon because of uncertainties in the fate of soil carbon upon conversion. It is likely that changes in management may have affected these trends, potentially even overriding the effect of land cover conversion. Closing this gap requires advancing the existing modeling approaches as well as collecting and harmonizing the information about land management regimes at the scale of the European continent. Only then it will be possible to determine whether the consequences of management explain the remaining difference between the model based-estimates of our study, estimates from ground-based data compilation $\left(235 \pm 50 \mathrm{TgC} \mathrm{yr}^{-1}\right)$, and atmospheric observations $\left(313 \pm 342 \mathrm{TgC} \mathrm{yr}^{-1}\right)$ (Schulze et al., 2009).

\section{Supplementary material related to this article is available online at: http://www.biogeosciences.net/7/2749/2010/ bg-7-2749-2010-supplement.pdf.}

Acknowledgements. This article benefited from the work done under the CARBOEUROPE project (No. GOCE-CT-2003505572) funded by the European Commission. The contribution of John Hughes and Chris Johns was also supported by the Joint DECC/Defra Met Office Hadley Centre Climate Program (GA01101). The authors are grateful for helpful discussions with Christian Rödenbeck and Ute Karstens.

The service charges for this open access publication have been covered by the Max Planck Society.

Edited by: U. Seibt 


\section{References}

Ainsworth, E. A. and Long, S. P.: What have we learned from 15 years of free-air $\mathrm{CO}_{2}$ enrichment (FACE)? A meta-analytic review of the responses of photosynthesis, canopy properties and plant production to rising $\mathrm{CO}_{2}$, New Phytol., 165, 351-372, 2005.

Bondeau, A., Smith, P. C., Zaehle, S., Schaphoff, S., Lucht, W., Cramer, W., Gerten, D., Lotze-Campen, H., Muller, C., Reichstein, M., and Smith, B.: Modelling the role of agriculture for the 20th century global terrestrial carbon balance, Glob. Change Biol., 13, 679-706, 2007.

Bouzaher, A., Carriquiry, A., and Jensen, H.: Structure of Ukrainian Agriculture: Comparative Efficiency and Implications for Policy Reform, Center for Agricultural and Rural Development (CARD), Iowa State University, Ames Iowa, Staff Report 94-SR 72, 115, 1994.

Chen, Y., Churkina, G., and Heimann, M.: Constructing a consistent historical climate data set for the European domain, MaxPlanck Institute for Biogeochemistry, Jena, Technical report 15, 30, 2009.

Churkina, G. and Running, S. W.: Investigating the balance between timber harvest and productivity of the global coniferous forests under global change, Clim. Change, 47, 167-191, 2000.

Churkina, G., Tenhunen, J., Thornton, P. E., Elbers, J. A., Erhard, M., Falge, E., Grünwald, T., Kowalski, A. S., Rannik, Ü., and Sprinz, D. F.: Analyzing the ecosystem carbon dynamics of four European coniferous forests using a biogeochemistry model, Ecosystems, 6, 168-184, 2003.

Churkina, G., Trusilova, K., Vetter, M., and Dentener, F. J.: Contributions of nitrogen deposition and forest re-growth to land carbon uptake, Carbon Balance and Management, 2(5), doi:10.1186/1750-0680-2-5, 2007.

Churkina, G., Brovkin, V., Von Bloh, W., Trusilova, K., Jung, M., and Dentener, F. J.: Synergy of rising nitrogen depositions and atmospheric $\mathrm{CO}_{2}$ on land carbon uptake offsets global warming, Global Biogeochem. Cy., 23, GB4027, doi:10.1029/2008GB003291, 2009.

Ciais, P., Borges, A. V., Abril, G., Meybeck, M., Folberth, G., Hauglustaine, D., and Janssens, I. A.: The impact of lateral carbon fluxes on the European carbon balance, Biogeosciences, 5, 1259-1271, doi:10.5194/bg-5-1259-2008, 2008a.

Ciais, P., Schelhaas, M. J., Zaehle, S., Piao, S. L., Cescatti, A., Liski, J., Luyssaert, S., Le-Maire, G., Schulze, E. D., Bouriaud, O., Freibauer, A., Valentini, R., and Nabuurs, G. J.: Carbon accumulation in European forests, Nature Geosci., 1, 425-429, 2008b.

Committee for the World Atlas of Agriculture: World Atlas of Agriculture, 527, 1969.

Cox, P. M., Betts, R. A., Jones, C. D., Spall, S. A., and Totterdall, I. J.: Acceleration of global warming due to carbon-cycle feedbacks in a coupled climate model, Nature, 408, 184-187, 2000.

Cox, P. M.: Description of the TRIFFID Dynamic Global Vegetation Model, Hadley Centre, Met Office, Exeter, UK, 16, 2001.

de Vries, W., Solberg, S., Dobbertin, M., Sterba, H., Laubhann, D., van Oijen, M., Evans, C., Gundersen, P., Kros, J., Wamelink, G. W. W., Reinds, G. J., and Sutton, M. A.: The impact of nitrogen deposition on carbon sequestration by European forests and heathlands, Forest Ecol. Manage., 258, 1814-1823, 2009.

Dentener, F. J., Drevet, J., Lamarque, J.-F., Bey, I., Eickhout, B.,
Fiore, A. M., Houglustaine, D., Horowitz, L. W., Krol, M., Kulshrestha, U. C., Lawrence, M., Galy-Lacaux, C., Rast, S., Shindell, D., Stevenson, D., Van Noije, T., Atherton, C., Bell, N., Bergmann, D., Butler, T., Cofala, J., Collins, B., Doherty, R., Ellingsen, K., Galloway, J. N., Gauss, M., Montataro, V., Muller, J. F., Pitari, G., Rodriguez, J., Sanderson, M., Solmon, F., Strahan, S., Schultz, M., Sudo, K., Szopa, S., and Wild, O.: Nitrogen and sulfur deposition on regional and global scales: a multimodel evaluation, Global Biogeochem. Cy., 20, GB4003, doi:10.1029/2005GB002672, 2006.

Economic Research Service: Structural Changes in West European Agriculture, 1950-1970, United States Department of Agriculture, 49, 1975.

Elser, J. J., Bracken, M. E. S., Cleland, E. E., Gruner, D. S., Harpole, W. S., Hillebrand, H., Ngai, J. T., Seabloom, E. W., Shurin, J. B., and Smith, J. E.: Global analysis of nitrogen and phosphorus limitation of primary producers in freshwater, marine and terrestrial ecosystems, Ecol. Lett., 10, 1135-1142, 2007.

Essery, R. L. H., Best, M. J., Betts, R. A., Cox, P. M., and Taylor, C. M.: Explicit Representation of Subgrid Heterogeneity in a GCM Land Surface Scheme, J. Hydrometeorol., 4, 530-543, 2003.

Etheridge, D. M., Steele, L. P., Langenfelds, R. L., Francey, R. J., Barnola, J.-M., and Morgan, V. I.: Natural and anthropogenic changes in atmospheric $\mathrm{CO}_{2}$ over the last 100 years from air in Antarctic ice and firn, J. Geophys. Res., 101, 4115-4128, 1996.

EUROSTAT: The Soviet Union, 1980 to 1991, Survey of the final years, 141, 1993.

Feser, F., Weisse, R., and von Storch, H.: Multi-decadal atmospheric modeling for Europe yields multi-purpose data, EOS Trans. Am. Geophys. Union, 82, 305, 2001.

Guo, L. B. and Gifford, R. M.: Soil carbon stocks and land use change: a meta analysis, Glob. Change Biol., 8, 345-360, 2002.

Hamilton, J. G., DeLucia, E. H., George, K., Naidu, S. L., Finzi, A. C., and Schlesinger, W. H.: Forest carbon balance under elevated $\mathrm{CO}_{2}$, Oecologia, 131, 250-260, 2002.

Harrison, R. G., Jones, C. D., and Hughes, J. K.: Competing roles of rising $\mathrm{CO}_{2}$ and climate change in the contemporary European carbon balance, Biogeosciences, 5, 1-10, doi:10.5194/bg-5-12008, 2008.

Hungate, B. A., Johnson, D. W., Dijkstra, P., Hymus, G., Stiling, P., Megonigal, J. P., Pagel, A. L., Moan, J. L., Day, F., Li, J., Hinkle, C. R., and Drake, B. G.: Nitrogen cycling during seven years of atmospheric $\mathrm{CO}_{2}$ enrichment in a scrub oak woodland, Ecology, 87, 26-40, doi:10.1890/04-1732, 2006.

Hurtt, G. C., Frolking, S., Fearon, M. G., Moore, B., Shevliakova, E., Malyshev, S., Pacala, S. W., and Houghton, R. A.: The underpinnings of land-use history: three centuries of global gridded land-use transitions, wood-harvest activity, and resulting secondary lands, Glob. Change Biol., 12, 1208-1229, 2006.

Jacob, D. and Podzun, R.: Sensitivity studies with the regional climate model REMO, Meteorol. Atmos. Phys., 63, 119-129, 1997.

Janssens, I. A., Freibauer, A., Ciais, P., Smith, P., Nabuurs, G.J., Folberth, G., Schlamadinger, B., Hutjes, R. W. A., Ceulemans, R., Schulze, E.-D., Valentini, R., and Dolman, A. J.: Europe's terrestrial biosphere absorbs 7 to $12 \%$ of European anthropogenic $\mathrm{CO}_{2}$ emissions, Science, 300, 1538-1542, 2003.

Johns, T. C., Durman, C. F., Banks, H. T., Roberts, M. J., McLaren, A. J., Ridley, J. K., Senior, C. A., Williams, K. D., Jones, A., Rickard, G. J., Cusack, S., Ingram, W. J., Crucifix, M., Sexton, 
D. M. H., Joshi, M. M., Dong, B.-W., Spencer, H., Hill, R. S. R., Gregory, J. M., Keen, A. B., Pardaens, A. K., Lowe, J. A., BodasSalcedo, A., Stark, S., and Searl, Y.: The New Hadley Centre Climate Model (HadGEM1): Evaluation of Coupled Simulations, J. Clim., 19, 1327-1353, 2006.

Jung, M., Herold, M., Henkel, K., and Churkina, G.: Exploiting synergies of land cover products for carbon cycle modelling, Remote Sens. Environ., 101, 534-553, 2006.

Jung, M., Le Maire, G., Zaehle, S., Luyssaert, S., Vetter, M., Churkina, G., Ciais, P., Viovy, N., and Reichstein, M.: Assessing the ability of three land ecosystem models to simulate gross carbon uptake of forests from boreal to Mediterranean climate in Europe, Biogeosciences, 4, 647-656, doi:10.5194/bg-4-647-2007, 2007a.

Jung, M., Vetter, M., Herold, M., Churkina, G., Reichstein, M., Zaehle, S., Ciais, P., Viovy, N., Bondeau, A., Chen, Y., Trusilova, K., Feser, F., and Heimann, M.: Uncertainties of modelling GPP over Europe: A systematic study on the effects of using different drivers and terrestrial biosphere models, Global Biogeochem. Cy., 21, GB4021, doi:10.1029/2006GB002915, 2007 b.

Kalnay, E., Kanamitsu, M., Kistler, R., Collins, W. J., Deaven, D., Gandin, L., Iredell, M., Saha, S., White, G., Woollen, J., Zhu, Y., Chelliah, M., Ebisuzaki, W., Higgins, W., Janowiak, J., Mo, C., Ropelewski, C., Wang, J., Leetmaa, A., Reynolds, R., Jenne, R., and Joseph, D.: The NCEP/NCAR reanalysis project, B. Am. Meteorol. Soc., 77, 437-471, 1996.

Keeling, C. D. and Whorf, T. P.: Atmospheric $\mathrm{CO}_{2}$ records from sites in the SIO air sampling network. In Trends: A Compendium of data on Global Change, Carbon Dioxide Information Analysis Center, Oak Ridge National Laboratory, Oak Ridge, Tenn., 2005.

Krinner, G. N., Viovy, N., de Noblet-Ducoudré, J., Ogée, J., Polcher, P., Friedlingstein, P., Ciais, P., Sitch, S., and Prentice, I. C.: A dynamic global vegetation model for studies of the coupled atmosphere-biosphere system, Global Biogeochem. Cy., 19, GB1015, doi:10.1029/2003GB002199, 2005.

LeBauer, D. S. and Treseder, K. K.: Nitrogen limitation of net primary productivity in terrestrial ecosystems is globally distributed, Ecology, 89, 371-379, doi:10.1890/06-2057.1, 2008.

Loveland, T. R., Reed, B. C., Brown, J. F., Ohlen, D. O., Zhu, Z., Yang, L., and Merchant, J. W.: Development of a global land cover characteristics database and IGBP DISCover from $1 \mathrm{~km}$ AVHRR data, Int. J. Remote Sens., 21, 1303-1330, 2000.

Magnani, F., Mencuccini, M., Borghetti, M., Berbigier, P., Berninger, F., Delzon, S., Grelle, A., Hari, P., Jarvis, P. G., Kolari, P., Kowalski, A. S., Lankreijer, H., Law, B. E., Lindroth, A., Loustau, D., Manca, G., Moncrieff, J. B., Rayment, M., Tedeschi, V., Valentini, R., and Grace, J.: The human footprint in the carbon cycle of temperate and boreal forests, Nature, 447, 849-851, 2007

Mitchell, T. D., Carter, T. R., Jones, P. D., Hulme, M., and New, M.: A comprehensive set of high-resolution grids of monthly climate for Europe and the globe: the observed record (1901-2000) and 16 scenarios (2001-2100), University of East Anglia, Norwich, 33, 2004.

Nabuurs, G.-J., Schelhaas, M.-J., Mohren, G. M. J., and Field, C. B.: Temporal evolution of the European forest carbon sink from 1950 to 1999, Glob. Change Biol., 9, 152-160, 2003.

Norwegian Census of Agriculture: Norwegian Statistical Yearbook, 496, 1991.
Organization for Economic Cooperation and Development: Agricultural Policies, Markets and Trade in Transition Economies, Monitoring and Evaluation 1996, 377, 1996.

Quinton, J. N., Govers, G., Van Oost, K., and Bardgett, R. D.: The impact of agricultural soil erosion on biogeochemical cycling, Nature Geosci., 3, 311-314, 2010.

Ramankutty, N. and Foley, J. A.: Estimating historical changes in global land cover: croplands from 1700 to 1992, Global Biogeochem. Cy., 13, 997-1028, 1999.

Ramankutty, N., Evan, A. T., Monfreda, C., and Foley, J. A.: Farming the planet: 1. Geographic distribution of global agricultural lands in the year 2000, Global Biogeochem. Cy., GB1003, doi:10.1029/2007GB002952, 2008.

Rodhe, H., Dentener, F. J., and Schulz, M.: The global distribution of acidifying wet deposition, Environ. Sci. Technol., 36, 43824388, 2002.

Running, S. W. and Gower, S. T.: FOREST-BGC, A general model of forest ecosystem processes for regional applications. II Dynamic carbon allocation and nitrogen budgets, Tree Physiol., 9, 147-160, 1991.

Schimel, D. S., House, J. I., Hibbard, K. A., Bousquet, P., Ciais, P., Peylin, P., Braswell, B. H., Apps, M. J., Baker, D., Bondeau, A., Canadell, J. G., Churkina, G., Cramer, W., Denning, A. S., Field, C. B., Fridlingstein, P., Goodale, C., Heimann, M., Houghton, R. A., Melillo, J. M., Moore III, B., Murdiyarso, D., Noble, I., Pacala, S. W., Prentice, I. C., Rauparch, M. R., Rayner, P. J., Scholes, R. J., Steffen, W. L., and Wirth, C.: Recent patterns and mechanisms of carbon exchange by terrestrial ecosystems, Nature, 414, 169-172, 2001.

Schulze, E. D., Luyssaert, S., Ciais, P., Freibauer, A., Janssens, I. A., et al.: Importance of methane and nitrous oxide for Europe's terrestrial greenhouse-gas balance, Nature Geosci., 2, 842-850, 2009.

Smith, P., Smith, J., Wattenbach, M., Meyer, J., Lindener, M., Zaehle, S., Hiederer, R., Jones, R. J. A., Montanarella, L., Rounsevell, M., Reginster, I., and Kankaanpää, S.: Projected changes in mineral soil carbon of European forests, 1990-2100, Can. J. Soil Sci., 86, 159-169, 2006.

Sutton, M. A., SIMPSON, D., Levy, P. E., Smith, R. I., Reis, S., van Oijen, M., and de Vries, W.: Uncertainties in the relationship between atmospheric nitrogen deposition and forest carbon sequestration, Glob. Change Biol., 14, 2057-2063, 2008.

Thornton, P. E., Law, B. E., Gholz, H. L., Clark, K. L., Falge, E., Ellsworth, D. E., Goldstein, A. H., Monson, R. H., Hollinger, D. Y., Falk, M., and Falk, J. P.: Modeling and measuring the effects of disturbance history and climate on carbon and water budgets in evergreen needleleaf forests, Agr. Forest Meteorol., 113, 185222, 2002.

Tomelleri, E.: Modeling the carbon cycle and its interactions with management practices in grasslands, $\mathrm{PhD}$, Universita degli Studi di Padova, Padova, 60 pp., 2007.

Trusilova, K., Trembath, J., and Churkina, G.: Parameter estimation and validation of the terrestrial ecosystem model BIOME-BGC using eddy -covariance flux measurements, Max-Planck Institute for Biogeochemistry, Jena, Technical report 16, 62, 2009.

Tupek, B., Zanchi, G., Verkerk, P. J., Churkina, G., Viovy, N., Hughes, J. K., and Lindner, M.: A comparison of alternative modelling approaches to evaluate the European forest carbon fluxes, Forest Ecol. Manage., 260, 241-251, 
doi:10.1016/j.foreco.2010.01.045, 2010.

Vetter, M., Wirth, C., Böttcher, H., Churkina, G., Schulze, E. D., Wutzler, T., and Weber, G.: Partitioning direct and indirect human-induced effects on carbon sequestration of managed coniferous forests using model simulations and forest inventories, Glob. Change Biol., 11, 810-827, 2005.

Vetter, M., Churkina, G., Jung, M., Reichstein, M., Zaehle, S., Bondeau, A., Chen, Y., Ciais, P., Feser, F., Freibauer, A., Geyer, R., Jones, C., Papale, D., Tenhunen, J., Tomelleri, E., Trusilova, K., Viovy, N., and Heimann, M.: Analyzing the causes and spatial pattern of the European 2003 carbon flux anomaly using seven models, Biogeosciences, 5, 561-583, doi:10.5194/bg-5561-2008, 2008.

Viovy, N.: Interannuality and $\mathrm{CO}_{2}$ sensitivity of the SECHIBABGC coupled SVAT-BGC model, Phys. Chem. Earth, 21, 489497, 1996.

White, M. A., Thornton, P. E., Running, S. W., and Nemani, R. R.: Parameterization and sensitivity analysis of the BIOME-BGC terrestrial ecosystem model: Net primary production controls, Earth Interactions, 4, 1-85, 2000.
Xia, J. and Wan, S.: Global response patterns of terrestrial plant species to nitrogen addition, New Phytol., 179, 428-439, 2008.

Zaehle, S., Sitch, S., Prentice, I. C., Liski, J., Cramer, W., Erhard, M., Hickler, T., and Smith, B.: The importance of age-related decline in forest NPP for modelling regional carbon balances, Ecol. Appl., 16, 1555-1574, 2006.

Zaehle, S., Bondeau, A., Carter, T., Cramer, W., Erhard, M., Prentice, I., Reginster, I., Rounsevell, M., Sitch, S., Smith, B., Smith, P., and Sykes, M.: Projected changes in terrestrial carbon storage in Europe under climate and land-use change, 1990-2100, Ecosystems, 10, 380-401, 2007.

Zaehle, S. and Friend, A. D.: Carbon and nitrogen cycle dynamics in the O-CN land surface model: 1. Model description, site-scale evaluation, and sensitivity to parameter estimates, Global Biogeochem. Cy., 24, GB1005, doi:10.1029/2009gb003521, 2010.

Zaehle, S., Friend, A. D., Dentener, F. J., Fridlingstein, P., Peylin, P., and Schulz, M.: Carbon and nitrogen cycle dynamics in the $\mathrm{O}-\mathrm{CN}$ land surface model, II: The role of the nitrogen cycle in the historical terrestrial carbon balance, Global Biogeochem. Cy., 24, GB1006, doi:10.1029/2009GB003522, 2010. 